\title{
Antigenic characterization and cytolocalization of P35, the major Mycoplasma penetrans antigen
}

\author{
Olivier Neyrolles, ${ }^{1} \dagger$ Jean-Pierre Eliane, ${ }^{1}$ Stéphane Ferris, ${ }^{1}$ \\ Regina Ayr Florio da Cunha, ${ }^{1} \neq$ Marie-Christine Prevost, ${ }^{1}$ \\ Elmostafa Bahraoui ${ }^{2}$ and Alain Blanchard ${ }^{1}$
}

1 Unité d'Oncologie Virale, Institut Pasteur, 28, rue du Dr. Roux, 75724 Paris Cedex 15, France

2 Laboratoire d'Immunovirologie UFR SVT, Université Paul Sabatier, 31062 Toulouse, France
Author for correspondence: Alain Blanchard. Tel: +331406131 31. Fax: +33140613465. e-mail: ablancha@pasteur.fr

Mycoplasma penetrans is a mycoplasma with unique morphology, recently identified in urine samples collected from HIV-infected patients. This mycoplasma has been found to be statistically associated with HIV infection, and to be cytopathic in vitro. The dominant antigen recognized during natural and experimental infections is an abundant lipoprotein, P35, which, upon extraction, segregates in the Triton $X-114$ detergent phase. It is used as the basis of $M$. penetrans-specific serological assays. Although mycoplasma lipoproteins, including $M$. penetrans P35, are the main antigens recognized by the host humoral immune response, very little is known about the nature of the epitopes involved. Immunoelectron microscopy revealed that all P35 is exposed at the cell surface and is distributed all over the membrane. P35 linear B-epitopes were mapped by an ELISA approach based on a set of overlapping peptides covering the entire mature polypeptide. The immunoreactivity of the peptides was first tested with sera from immunized animals. The dominant Bepitopes were found at the $\mathrm{C}$ - and $\mathrm{N}$-terminal regions, in partial agreement with algorithmic predictions. Patient sera were evaluated with the same assay. Only some reacted with linear epitopes whereas others did not, indicating the importance of P35 nonsequential epitopes. Statistical analysis of the results allowed the definition of a set of peptides which were clearly immunodominant. Finally, the P35-encoding gene was modified by in vitro mutagenesis to allow the production and purification of a recombinant protein $(r P 35 \Delta 0)$ in Escherichia coli. The antigenicity of rP35 $\Delta 0$ was tested by Western blotting and compared to that of another recombinant product, $\operatorname{rP35} \Delta 3$, a truncated P35 polypeptide. Although rP35 $\triangle 0$ reacted with the $M$. penetransseropositive patient sera tested, $\mathrm{rP35 \Delta 3}$ was only immunoreactive with one of six sera. This result confirmed that P35-nonsequential epitopes dominate during $M$. penetrans infection. Our results have important implications for the understanding of lipoprotein antigenicity during mycoplasma infections. In addition, the P35-derived immunodominant synthetic peptides defined in this study, as well as the purified rP35 $\Delta 0$, provide the antigenic material for the necessary improvement of $M$. penetrans serological assays.

Keywords: epitope mapping, lipoprotein, immunogenicity, Mycoplasma penetrans

\footnotetext{
†Present address: Imperial College School of Medicine at St Mary's, Department of Medical Microbiology, Norfolk Place, London W2 1PG, UK. ¥Present adress: Faculdade de Ciencas Farmaceuticas, Universidade de São Paulo, Av. Linen Prestes no 580-Bloco 17, CEP 05508-900 São Paulo, Brazil. Abbreviations: $\mathrm{Al}$, antigenic index; $\mathrm{CO}_{50}$, cut-off $50 \%$; CCU, colour-changing unit; Pam3-CYS, (palmitic acid) ${ }_{3}$-Cys-Ser-Lys ${ }_{4}-\mathrm{OH}$; TEM, transmission electron microscopy.
} 


\section{INTRODUCTION}

Mycoplasma penetrans is a novel mollicute species with a unique morphology characterized by an elongated flask shape with a densely packed terminal tip-like structure. It penetrates eukaryotic cells (hence its name), has cytopathic effects in vitro (Giron et al., 1996; Lo et al., 1992), and activates peripheral T-lymphocytes from both HIV-seronegative and -seropositive individuals (Sasaki et al., 1995). M. penetrans was initially isolated from urine samples from six HIV-infected male homosexuals (Lo et al., 1991a, 1992), and sero-epidemiological studies demonstrated that $M$. penetrans was associated with HIV infection, at least among male homosexual populations (Grau et al., 1995; Wang et al., 1992, 1993). As some mycoplasmas can act in synergy with HIV to induce cell killing in vitro (Lemaitre et al., 1992; Lo et al., 1991b), we have suggested that M. penetrans may be a cofactor of HIV in viral transmission and/or disease progression (Blanchard, 1997; Blanchard \& Montagnier, 1994; Blanchard et al., 1997; Brenner, 1996; Grau et al., 1998). Until recently, M. penetrans had only been isolated from HIV-infected patients, and was not associated with any pathology. However, the recent isolation of this mycoplasma from an HIVseronegative person suffering a primary anti-phospholipid syndrome suggests that $M$. penetrans may, at least under certain circumstances, be pathogenic (A. Yanez and others, unpublished).

As $M$. penetrans isolation from clinical samples is extremely complex and time-consuming (Lo et al., 1991a, 1992), infections with this mycoplasma are almost exclusively detected by serological assays using a Triton X-114 extract of the mycoplasma to detect $M$. penetrans-specific antibodies (Wang et al., 1992). This extract contains two major polypeptides with molecular masses of $35 \mathrm{kDa}$ (P35) and $38 \mathrm{kDa}(\mathrm{P} 38)$. P35 and P38 are acylated, and we have isolated and sequenced the p35 gene, which encodes P35 (Ferris et al., 1995). The p35 sequence encodes a polypeptide with an $\mathrm{N}$-terminal signal sequence with a cleavage site for signal peptidase II. Since some sera containing antibodies against $\mathrm{Myco-}$ plasma pneumoniae or Ureaplasma urealyticum crossreact with $\mathrm{P} 38$, it was proposed to restrict the criteria for diagnosing $M$. penetrans seropositivity to a $\mathrm{P} 35$-specific reaction in Western blotting (Grau et al., 1995).

The goal of this study was to further characterize P35, the major $M$. penetrans antigen. Its antigenicity was studied. To define sequential epitopes of this lipoprotein, we tested a set of overlapping synthetic peptides by ELISA against different sera, an approach similar to that previously used for other bacterial lipoprotein antigens such as PAc from Streptococcus mutans (Matsushita $e t$ al., 1994), OspA from Borrelia burgdorferi (Ma et al., 1995 ) and TmpA from Treponema pallidum (Antoni et al., 1996). The antigenicity of recombinant $\mathrm{P} 35$ and of a truncated P35 was also evaluated. Finally, we investigated the antigenicity of different post-translationally modified P35 polypeptides.

\section{METHODS}

Growth conditions and antigen preparation. $M$. penetrans (strain GTU-54-6A1), initially isolated by S.-C. Lo (Armed Forces Institute of Pathology, Bethesda, MD, USA), was kindly provided by J. Tully (National Institute of Allergy and Infectious Diseases, Frederick, MD, USA) and was cultured in SP-4 medium containing $10 \%(\mathrm{v} / \mathrm{v})$ foetal calf serum (Tully et al., 1977). To determine whether or not $\mathrm{P} 35$ is phosphorylated, mycoplasmas were cultured for $24 \mathrm{~h}$ at $37^{\circ} \mathrm{C}$ in complete SP4 medium containing $\mathrm{H}_{3}{ }^{32} \mathrm{PO}_{4}$ (Amersham) at $9.25 \times 10^{4} \mathrm{~Bq}$ $(\mathrm{ml} \text { culture medium })^{-1}$. M. penetrans antigens were extracted with the neutral detergent Triton X-114 and amphiphilic polypeptides, which include lipoproteins, were concentrated by detergent-phase partitioning as previously described (Ferris et al., 1995).

Animal and human sera. Two rabbits (1 and 2 ) and one macaque (9063) were immunized with the Triton $\mathrm{X}-114$ extract from M. penetrans, as previously described (Grau et al., 1995). Another rabbit (3) was immunized with a Cterminal synthetic peptide from the P35 ( $\mathrm{V}^{288} \mathrm{KSEKDSTN}$ NNKYTVTLK ${ }^{305}$ ), and the hyperimmune serum was used as a positive control in the epitope-mapping assay (see below). Murine anti-P35 monoclonal antibody (mAb 7, purified IgG1 from ascitic fluid, $300 \mu \mathrm{g} \mathrm{ml}^{-1}$ ) was kindly provided by $\mathrm{T}$. Sasaki (National Institute of Health, Tokyo, Japan). In another study conducted in our laboratory, three macaques $\langle 91810,92926$ and 8670$\rangle$ were experimentally infected with $M$. penetrans strain GTU-54-6A1. The sera used were those collected when the strongest humoral response against P35 was detected by Western blotting.

The seropositivity of human sera to $M$. penetrans was first tested by ELISA using the detergent phase of the Triton X-114 extraction from $M$. penetrans as antigen. Sera positive in the ELISA were tested by Western blotting: reaction with the P35 polypeptide was required to diagnose $M$. penetrans seropositivity, as previously determined (Grau et al., 1995)

Growth-inhibition assay. To evaluate the ability of the various antibodies to inhibit $M$. penetrans growth, serial 10 -fold dilutions of the mycoplasma were cultured in complete SP-4 medium containing the antibody at the dilution indicated. After incubation at $37^{\circ} \mathrm{C}$ for $3-4 \mathrm{~d}$, the colour change of the serial dilutions was compared to that of a culture without any antibody. The ability of antibodies to inhibit $M$. penetrans growth was expressed as the logarithm of the difference between the two cultures. Each experiment was performed in duplicate.

Protein quantification, SDSPAGE and Western blotting. Protein concentrations were determined using the Micro BCA Protein Assay Reagent Kit (Pierce). SDS-PAGE was conducted according to Laemmli (1970) and proteins were stained with Coomassie blue. For Western blotting, the proteins resolved by SDS-PAGE were electro-transferred onto nitrocellulose membranes at $4 \mathrm{~mA} \mathrm{~cm} \mathrm{~cm}^{-2}$ for $1 \mathrm{~h}$. Membrane-bound polypeptides were immunologically detected as previously described (Ferris et al., 1995). Putative glycosylation with mannose or glucose residues in P35 was evaluated by a Western blotting technique using a peroxidase-conjugated Canavalia ensiformis lectin (ConA) as described for the identification of $\mathrm{N}$ - and $\mathrm{O}$-glycosylated bacterial proteins such as the $19 \mathrm{kDa}$ antigen from Mycobacterium tuberculosis (Garbe et al., 1993; Herrmann et al., 1996).

Transmission electron microscopy (TEM) and immunogold labelling. Immunogold labelling was used on whole cells and 
on ultra-thin sections with $0.03 \mathrm{mg} \mathrm{mAb} 7 \mathrm{ml}^{-1}$ to locate the P35 polypeptide in the mycoplasma cell. For immunogold labelling of whole mycoplasma cells, the procedure described by Le Gall et al. (1997) was followed. The secondary antibodies (goat anti-mouse; Amersham) were conjugated with $10 \mathrm{~nm}$ gold particles and the grids were negatively stained with $1 \%(\mathrm{w} / \mathrm{v})$ phosphotungstic acid. Immunogold labelling of ultra-thin cryosections was as described by Adam et al. (1995), except that mycoplasmas were fixed with $4 \%(\mathrm{w} / \mathrm{v})$ paraformaldehyde and $0.1 \%(\mathrm{v} / \mathrm{v})$ glutaraldehyde before ultra-thin sectioning with a cryotome, and the detergent Tween 20 was omitted from the washes. The secondary antibodies (goat anti-mouse; Amersham) were conjugated with $5 \mathrm{~nm}$ gold particles. The preparations were examined with a 1200 EX electron microscope (JEOL) operating at an accelerating voltage of $80 \mathrm{kV}$.

ELISA. Microtitre plates were coated with $M$. penetrans Triton X-114 extract as described by Grau et al. (1995). In some experiments, the Triton X-114 extract was digested by proteinase $\mathrm{K}$ ( $1 \mu \mathrm{g}$ per $2.5 \mu \mathrm{g}$ protein) for $2 \mathrm{~h}$ at $56^{\circ} \mathrm{C}$ prior to coating as indicated; the disappearance of Coomassie bluestainable polypeptides resulting from the proteinase $\mathrm{K}$ treatment was verified by SDS-PAGE. When $\mathrm{Pam}_{3}$-CYS ([palmitic acid $]_{3}$-Cys-Ser-Lys 4 -OH; Boehringer Mannheim) was used as the antigen, it was coated in $0.2 \%(\mathrm{w} / \mathrm{v})$ TCA for $1 \mathrm{~h}$ at $37^{\circ} \mathrm{C}$. For reduction and alkylation of putative disulphide bonds in P35, the Triton X-114 extract was pre-treated with $10 \mathrm{mM}$ DTT and $50 \mathrm{mM}$ iodoacetamide for $30 \mathrm{~min}$ at room temperature.

Linear B-epitope mapping. A set of 81 overlapping dodecapeptides (12-mers) covering the complete amino acid sequence of mature P35 was synthesized on polyethylene pins by Chiron Mimotopes as reported by Geysen $e t$ al. (1987). Each peptide overlapped the preceding one by eight amino acids. The peptides were provided in solution after cleavage from the polyethylene pins. The quality of the synthesis was evaluated by analytical HPLC amino acid analysis of two control peptides, and the serological reactivity of an uncleaved peptide was verified with control serum. To optimize the recognition conditions by sera, the peptides were linked at the C-terminus to a biotin-SGSG arm which allowed peptide binding to streptavidin-coated plates. Lyophilized peptides $(1.2 \mu \mathrm{mol})$ were resuspended in $200 \mu \mathrm{l}$ DMSO and kept at $-80^{\circ} \mathrm{C}$. Working solutions were obtained by diluting this DMSO stock to $1 \%(\mathrm{v} / \mathrm{v})$ in PBS, $0.1 \%(\mathrm{w} / \mathrm{v}) \mathrm{BSA}, 0.01 \%(\mathrm{w} / \mathrm{v})$ sodium azide, and were stored at $4{ }^{\circ} \mathrm{C}$ until use. Streptavidin was coated onto 96 -well microplates at $100 \mathrm{ng}$ per well in carbonate/bicarbonate buffer, $\mathrm{pH} 9 \cdot 6$, for $1 \mathrm{~h}$ at $37^{\circ} \mathrm{C}$. Peptide working solutions were diluted $1: 10$ in PBS, $0.1 \%$ BSA and coated onto plates by incubation for $1 \mathrm{~h}$ at room temperature. The reactivities of peptides with antibodies were determined by ELISA according to the manufacturer's instructions (Chiron Mimotopes). The bound antibodies were detected with either peroxidase-conjugated goat anti-mouse IgG (heavy and light chains; Bio-Rad) or anti-human IgG (heavy and light chains; Bio-Rad). A peptide was scored as being specifically recognized only if the serum from the same animal obtained prior to the experimental infection did not react. As a positive control, the hyperimmune serum from rabbit 3 was used in ELISA against the appropriate biotinylated peptides.

Epitope prediction and statistical analysis of the data. The method of Jameson \& Wolf (1988) was used to predict the antigenicity of the mature $\mathrm{P} 35$. The antigenic index (AI) was deduced from the index of hydrophilicity $(\mathrm{H})$, flexibility $(\mathrm{F})$, surface probability (SP), and the predicted secondary structure of the molecule according to Chou \& Fasman [CF; Chou \& Fasman (1978)] and Garnier et al. [RG; (Garnier et al., 1978)], using the formula: $\mathrm{AI}=0 \cdot 3 \mathrm{H}+0 \cdot 15 \mathrm{SP}+0 \cdot 15 \mathrm{~F}+0 \cdot 2 \mathrm{CF}-$ $+0 \cdot 2$ RG. A cut-off value of 1.35 was obtained using the formula mean $+(4 \times \mathrm{SD})$ on the $166(50 \%)$ lowest AI values.

Data obtained from epitope mapping with human sera were analysed as follows. For each serum, the mean $(\mu)$ and the standard deviation $(\sigma)$ of the 40 lowest values at $A_{490}$ (which correspond to $50 \%$ of the data) were calculated and the cut-off $50 \%\left(\mathrm{CO}_{50}\right)$ was calculated as $\mathrm{CO}_{50}=\mu+4 \sigma$. An $A_{490}$ was considered positive when higher than $\mathrm{CO}_{50}$. Due to the size of populations, the exact Fisher method was used and calculations were performed using the STATISTICA software (StatSoft). For human sera, a frequency of peptide recognition $\geqslant 25 \%$ was considered significant.

Cloning and mutagenesis of the $p 35$ gene and production of recombinant proteins. The gene encoding the $\mathrm{P} 35$ polypeptide lacking the $5^{\prime} \mathrm{N}$-terminal signal sequence-encoding fragment was amplified by PCR from the plasmid pMP11 (Ferris et al., 1995) using the following primers: 5' TACGGGATCCTTCTTCTTGTTCTTCTACAAGTGAAAAC $3^{\prime}$ and $5^{\prime}$ TCGATCCAATTGTCTGCAGGCTAAAAGTTGC $3^{\prime}$. The underlined nucleotides were added for cloning purposes and correspond to Bam HI and Pst I restriction sites, respectively. PCR amplification was performed with 20 pmol each primer, $25 \mathrm{mM}$ each dNTP, $10 \mu \mathrm{l} 10 \times$ Taq DNA polymerase buffer and $2.5 \mathrm{U}$ Taq DNA polymerase (Perkin Elmer) in a final volume of $100 \mu \mathrm{l}$. The thermal profile was initial denaturation at $95^{\circ} \mathrm{C}$ for $5 \mathrm{~min}$, followed by 35 cycles of denaturation at $95^{\circ} \mathrm{C}$ for $1 \mathrm{~min}$, primer annealing at $55^{\circ} \mathrm{C}$ for $1 \mathrm{~min}$ and extension at $72{ }^{\circ} \mathrm{C}$ for $2 \mathrm{~min}$, and finally an incubation at $72^{\circ} \mathrm{C}$ for $10 \mathrm{~min}$. The $1 \mathrm{~kb}$ amplicon was digested with BamHI and Pst $\mathrm{I}$, and ligated to Bam $\mathrm{HI} /$ Pst $\mathrm{I}$-digested $\mathrm{pQE} 31$ (Qiagen). In the construct obtained, the $p 35$ gene is under the control of a regulated promoter and the recombinant protein is fused to a $\mathrm{His}_{6} \mathrm{~N}$-terminal tag. The two TGA triplets within the $p 35$ gene were changed to TGG triplets (encoding tryptophan universally) by PCR-mediated mutagenesis (QuickChange Site-Directed Mutagenesis Kit; Stratagene). The mutated plasmid allowing $p 35$ translation in E. coli was designated pQEP35 $\triangle 0$, and encoded a polypeptide with a calculated molecular mass of $37 \cdot 4 \mathrm{kDa}$. This plasmid was also subjected to another PCR-mediated mutagenesis using the primer p35mut3 ( 5 ' AACAGCAAAAGATGGTACAAACAGATGTTAGTATGG $3^{\prime}$ ) to insert a frame-shift mutation at the underlined position. The plasmid obtained was designated pQEP35 $\triangle 3$, and encoded a truncated form of P35 $\left(\mathrm{C}^{1}-\mathrm{G}^{182}\right)$ with a calculated molecular mass of $21.6 \mathrm{kDa}$. The relevant sequences in both $\mathrm{pQEP} 35 \Delta 0$ and $\mathrm{pQEP} 35 \Delta 3$ were verified by DNA sequencing.

For the expression of recombinant products, each $\mathrm{pQE}$ derived plasmid was used to transform the M15(pREP4) strain of $E$. coli supplied with the QIAexpressionist Kit (Qiagen). E. coli transformants containing either $\mathrm{pQEP} 35 \Delta 0$ or $\mathrm{pQEP} 35 \Delta 3$ were grown at $37^{\circ} \mathrm{C}$ with shaking in 11 of $\mathrm{LB}$ medium supplemented with $25 \mu \mathrm{g}$ kanamycin $\mathrm{ml}^{-1}$ and $100 \mu \mathrm{g} \mathrm{am}-$ picillin $\mathrm{ml}^{-1}$ to $\mathrm{OD}_{0 \cdot 6}$. Production of the recombinant proteins was induced by the addition of IPTG to the bacterial culture, to a final concentration of $2 \mathrm{mM}$, and incubation for $5 \mathrm{~h}$ at $37^{\circ} \mathrm{C}$. E. coli cells were then recovered by centrifugation at $12000 \mathrm{~g}$ for $10 \mathrm{~min}$ at $4{ }^{\circ} \mathrm{C}$ and the pellets were stored overnight at $-20^{\circ} \mathrm{C}$. Bacteria were then thawed and lysed by sonication in $50 \mathrm{mM} \mathrm{NaH} \mathrm{PO}_{4}, 300 \mathrm{mM} \mathrm{NaCl}$, pH 8.0, at $0{ }^{\circ} \mathrm{C}$, and the cytoplasmic fraction was obtained by centri- 
Fig. 1. Specific reactivity of sera with the $M$. penetrans Triton X-114-extracted polypeptides, as shown by Western blotting. The pre-immune (lanes 1 and 3 ) and hyperimmune (lanes 2 and 4) sera from rabbit 1 and 2 were tested at 1:500 dilution. The monospecific anti-P35 preimmune (lane 5 ) and hyperimmune (lane 6) sera from rabbit 3 were tested at 1:100 dilution. The murine anti-P35 mAb 7 (lane 7) was tested at 1:2000 dilution. $M$. penetransseronegative (lane 8) and -seropositive (lane 9) human sera were tested at 1:100 dilution. fugation $\left(7000 \mathrm{~g}, 1 \mathrm{~h}, 4^{\circ} \mathrm{C}\right)$. A volume of cytoplasmic fraction containing about $22 \mathrm{mg}$ protein was loaded onto a nickel affinity Sepharose column (HisTrap; Pharmacia) and the histidine-tagged recombinant protein was eluted by an imidazole gradient $(0-500 \mathrm{mM})$ in $50 \mathrm{mM} \mathrm{NaH} \mathrm{PO}_{4}, 300 \mathrm{mM}$ $\mathrm{NaCl}, 10 \%(\mathrm{v} / \mathrm{v})$ glycerol $(\mathrm{pH} 8.0)$. The fractions containing the recombinant P35 (rP35 $\Delta 0)$ and the truncated P35 (rP35 $\Delta 3$ ) contained $2 \mathrm{mg}$ and $1.5 \mathrm{mg}$ protein, respectively. Imidazole was removed by overnight dialysis at $4^{\circ} \mathrm{C}$ against $50 \mathrm{mM}$ $\mathrm{NaH}_{2} \mathrm{PO}_{4}, 300 \mathrm{mM} \mathrm{NaCl}, 10 \%$ (v/v) glycerol (pH 8.0). The $\mathrm{rP} 35 \Delta 0$ and $\mathrm{rP} 35 \Delta 3$ proteins were identified on the basis of their molecular masses and their immunoreactivity with the polyclonal hyperimmune sera from rabbit 2 . They were tested for antigenicity with other sera by Western blotting as described previously (Grau et al., 1995).

\section{RESULTS}

\section{Specificity of the anti-M. penetrans antibodies}

The specificity of the various sera for polypeptides in the M. penetrans Triton X-114 extract was evaluated (Fig. 1). Sera from the two immunized rabbits, 1 and 2, (lanes 2 and 4 ) and the $M$. penetrans-seropositive human serum (lane 9) reacted with the three major polypeptides in this Triton X-114 extract: P30, P35 and P38. As expected, the hyperimmune serum from rabbit 3 , which was immunized with a C-terminal synthetic peptide from P35, reacted with the P35 polypeptide only (Fig. 1, lane 6). $\mathrm{mAb} 7$ reacted with the $\mathrm{P} 35$ polypeptide only (Fig. 1, lane 7).

To evaluate the neutralizing ability of the anti-M. penetrans antibodies, mycoplasma cells were cultured in the presence of the different sera. Mycoplasma growth was measured as CCU and growth of the control culture without antiserum used as the reference. $\mathrm{mAb} 7$ and sera from immunized rabbits inhibited $M$. penetrans growth similarly $(-2 \log C C U)$. Sera from infected humans also inhibited mycoplasma growth but to different degrees $(-1$ to $-2 \log C \mathrm{CU})$. The serum from a macaque experimentally infected with $M$. penetrans and preimmune sera did not inhibit mycoplasma growth.

\section{Cellular localization of the P35 antigen}

The cellular localization of the P35 antigen was investigated using immunogold electron microscopy. mAb 7 bound to the surface of mycoplasmas, with both the tip and the cell body being labelled (Fig. 2a). To test whether P35 was only found at the cell surface, ultrathin sections of mycoplasma cells were probed with $\mathrm{mAb} 7$; the labelling was found only on the external surface of the M. penetrans plasma membrane (Fig. 2b). This demonstrates that the P35 lipoprotein is a polypeptide exposed externally on the cell surface. Presumably it is anchored to the lipid bilayer through its $\mathrm{N}$ terminal acyl moiety.

\section{P35 linear B-epitopes recognized by immunized animal sera}

The formula described by Jameson \& Wolf (1988) was used to predict the antigenicity of the mature P35 (Fig. $3)$. The calculation of a $\mathrm{CO}_{50}$ value $(1.35)$ for the $\mathrm{AI}$ allowed prediction of the main epitopes. There were six: one at the $\mathrm{N}$-terminus, two at the $\mathrm{C}$-terminus and three other regions in the middle of the sequence (Fig. 3). To localize sequential B-epitopes in P35, a set of 81 dodecapeptides covering the whole P35 primary sequence was synthesized. The peptides corresponding to the six predicted antigenic regions were: $1,2,15-17$, $37-39,44,45,73-75$ and $76-78$. 


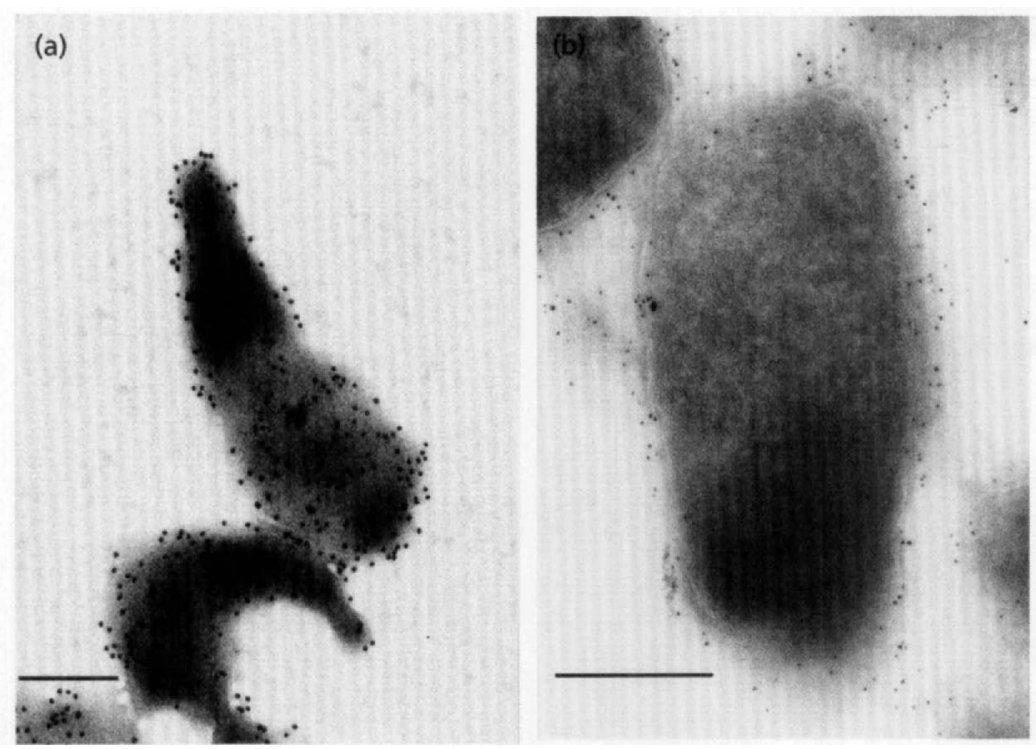

Fig. 2. Immunogold labelling of the P35 lipoprotein at the surface of $M$. penetrans cells. Electron microscopic examination of whole $M$. penetrans cells (negative staining; a) or ultra-thin cryosections (b) after incubation with the murine anti-P35 mAb 7. The gold particles conjugated to the secondary antibodies were $10 \mathrm{~nm}$ (a) or $5 \mathrm{~nm}(\mathrm{~b})$ in diameter. Bars, $200 \mathrm{~nm}$.

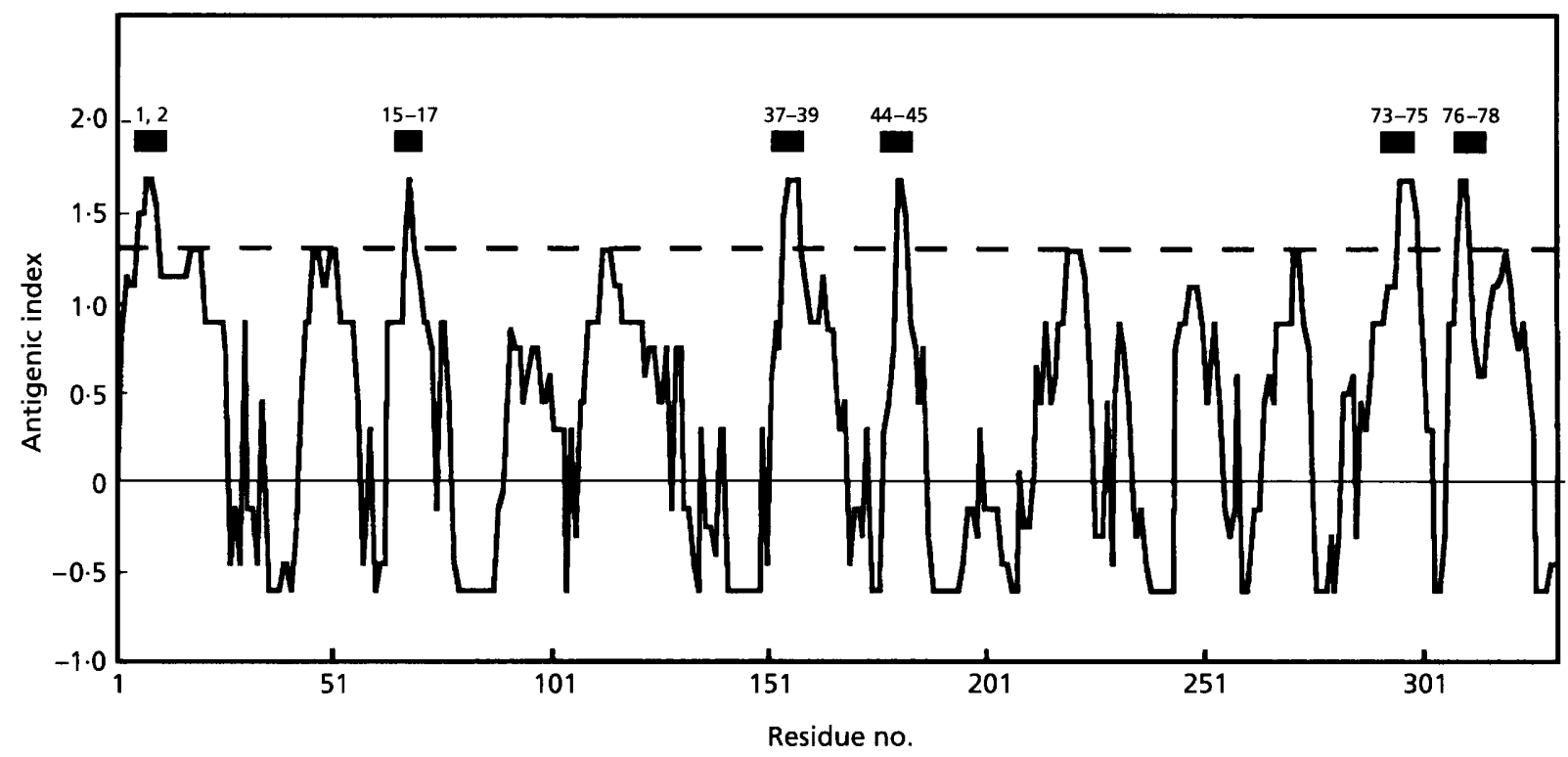

Fig. 3. Theoretical predictions of the antigenicity of P35. The dashed line indicates the calculated cut-off value. The black bars above the peaks indicate the peptide numbers of the synthetic peptides overlapping the P35 regions with the highest predicted antigenicity.

The reactivity of the 81 peptides with the various sera was tested by ELISA. Sera from pre-immune animals did not react with the peptides (Fig. $4 \mathrm{a}, \mathrm{d}$ for rabbit 1 and macaque 9063, respectively). The sera from rabbits immunized with the Triton X-114 extract reacted with several peptides mostly clustered at the $\mathrm{N}$ - and Ctermini of P35 (Fig. 4b, c for rabbits 1 and 2, respectively). In particular, successive pairs of peptides within the N-terminal end of $\mathrm{P} 35$ reacted with the serum from rabbit 1 . It is likely that their antigenic determinants correspond to the common sequences: $\mathrm{T}^{17}$ DGNTQQT ${ }^{24}$ for peptides 4 and $5, \mathrm{~T}^{37}$ GALSKIY ${ }^{44}$ for peptides 9 and 10 , and $A^{64}$ NPENYFT $^{71}$ for peptides
16 and 17 (Fig. 4b). Similarly, pairs of peptides with common sequences were found to react with the serum from rabbit $2, \mathrm{~T}^{37} \mathrm{GALSKIY}^{44}$ for peptides 9 and 10 , $\mathrm{A}^{64}$ NPENYFT ${ }^{71}$ for peptides 16 and 17 , and $\mathrm{N}^{129}$ DLQTVLG $^{\mathbf{1 3 6}}$ for peptides 32 and 33 . The single peptide $14\left(\mathrm{E}^{52} \mathrm{TTSQLIVKDIK}^{63}\right)$ also reacted with this serum. Within the C-terminal region, clusters of peptides reacted : peptides $60-65$ and $73-76$ for rabbit 1, with two major reacting sequences corresponding to peptides 63 $\left(\mathrm{N}^{249} \mathrm{AEKVLEKLGYA}{ }^{260}\right)$ and $74\left(\mathrm{D}^{293} \mathrm{STNNNKYT-}\right.$ $\mathrm{VTL}^{304}$ ), and peptides $73-77$ for rabbit 2 with a major reacting sequence corresponding to peptides 76 and 77 $\left(\mathrm{K}^{305} \mathrm{ATPNDGY}{ }^{312}\right)$. Both rabbit sera reacted with the 


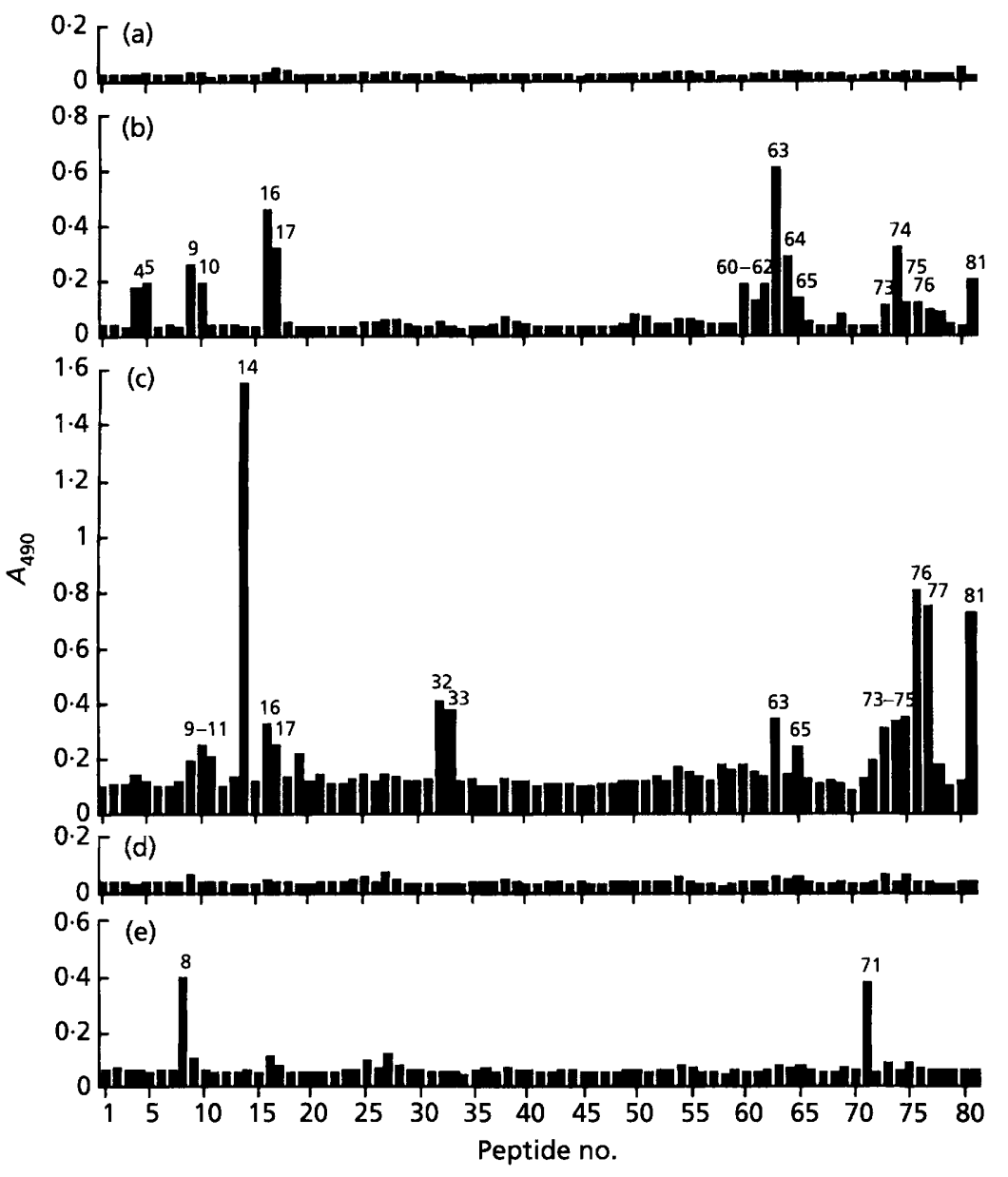

Fig. 4. Linear B-epitope mapping of $M$. penetrans P35 with sera from immunized animals. Sera from preimmunized rabbit 1 (a) and hyperimmune rabbits 1 and $2(b, c)$ were tested at a 1:500 dilution. Preimmunized (d) and immunized (e) macaque 9063 sera were tested using a $1: 200$ dilution. All reaction peaks were tested for specificity by pre-incubation of the serum with the peptide prior to ELISA and the number of the corresponding peptide(s) is indicated only if there was a specific reaction.
C-terminal peptide $81 \quad\left(\mathrm{~A}^{321} \mathrm{KEEISFVATFS}{ }^{332}\right)$. The reactivity of the serum from the immunized macaque 9063 was weaker. Only the 2 peptides, 8 (A ${ }^{29}$ IKSEVSLTGAL $^{40}$ ) and 71 ( ${ }^{281}$ NCKFEAVKSEK $^{292}$ ), were significantly recognized (Fig. 4e). The specificity of all these reactions was evaluated by inhibition assays in which the sera were pre-incubated with the corresponding peptide prior to their addition to the coated peptide in the ELISA. This pre-incubation resulted in the complete inhibition of the signal, confirming the specificity of the reaction (data not shown).

\section{P35 linear B-epitope mapping using sera from $\boldsymbol{M}$. penetrans-infected humans and macaques}

Various reactivities were obtained with human sera (Fig. 5, Table 1). No peptide reacted with the sera from HIV- and $M$. penetrans-seronegative subjects and the background level was low $\left(A_{490}\right.$ around $0 \cdot 03$; Fig. 5a). In contrast, all sera from HIV-infected persons exhibited a higher background level with $A_{490}$ close to $0 \cdot 1$ (Fig. $5 \mathrm{~b}$, $c$ and $d$ ). Some of the 14 sera from HIV-seropositive but M. penetrans-seronegative patients reacted with a few peptides (Fig. 5b); only peptides 2, 4, 7, 12, 13 and 73 were significantly $(\geqslant 25 \%)$ recognized. Profiles obtained with sera from patients seropositive for both HIV and
M. penetrans were of two types: some exhibited low reactivity with the peptides (Fig. $5 \mathrm{c}$ ), suggesting that they were directed against nonsequential rather than linear epitopes, whereas others recognized various peptides more strongly (Fig. 5d). Peptides 1, 2, 7, 11, 12, $13,25,37,49,60,73,74,75,76,77$ and 78 were significantly recognized $(\geqslant 25 \%)$ by at least seven of the 26 sera from this population. Most of these peptides were also recognized by the only HIV-seronegative and M. penetrans-seropositive serum that was tested (Table 1).

Many of the peptides recognized by $M$. penetrans seropositive sera were often clustered. The reaction profile shown on Fig. 5 (d) indicates that the serum recognized peptides $1,12-14,24,25,35-37,48,49,60$, 61 and others in the C-terminal region of the protein. Presumably this serum contains antibodies directed against the sequence common to clustered peptides: for example $\left(\mathrm{F}^{97}\right.$ TGEAYSV $\left.^{104}\right)$ for peptides 24 and 25 , which is not present on peptides 23 and 26. Similarly, for peptides $35-37$ and 48-50, the epitopes probably correspond to the regions included in sequences $\mathrm{C}^{145}$ DLIPNLKLNNG ${ }^{156}$ and $\mathrm{L}^{197}$ NLKIDGLKISV ${ }^{208} \mathrm{re-}$ spectively, which, interestingly, share the same NLK tripeptide. 


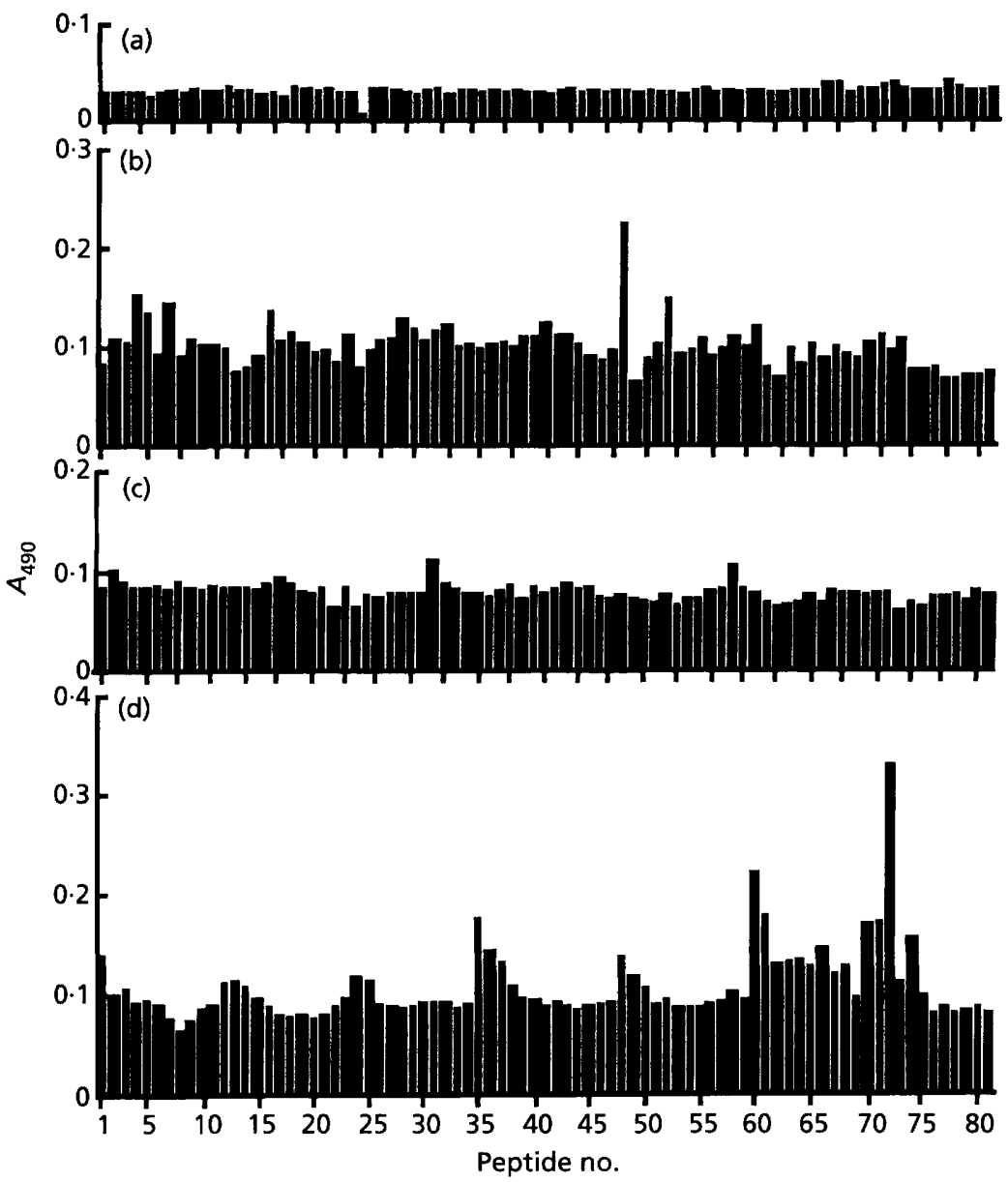

Fig. 5. Linear B-epitope mapping of $M$. penetrans P35 with sera from $M$. penetransseropositive and -seronegative patients. The profile for one HIV- and $M$. penetransseronegative patient is shown in (a) and for one HIV-seropositive and $M$. penetransseronegative patient in (b). The profiles for two HIV- and $M$. penetrans-seropositive patient are shown in (c) and (d). All sera were tested at a 1:100 dilution. The calculated $\mathrm{CO}_{50}$ values were $0.031,0.129$, 0.092 and 0.109 , respectively.
The serum from the $M$. penetrans-infected macaque 91810 reacted specifically with peptides $7,8,14,16,17$, $24,25,31,61$ and 64 . Serum from the infected macaque 92926 reacted specifically with peptide 7 , and that from infected macaque 8670 with peptides $25,36,38,50$ and 61 . These results are summarized in Table 1 . Note that peptide 25 , which is the most widely recognized by human sera, was also recognized by two of the three experimentally infected macaques.

\section{Involvement of the $\mathrm{N}$-terminal acylated cysteine and of other post-translational modifications in the antigenicity of the $M$. penetrans Triton X-114- extracted antigens}

The involvement of the $\mathrm{N}$-terminal acylated structure of P35 in its antigenicity was evaluated by ELISA (Fig. 6a). Proteinase $\mathrm{K}$ treatment of the Triton X-114 extracted antigens totally abolished reactivity with nine $M$. penetrans seropositive sera. However, in one case (serum 3 ) the signal was not completely abolished after proteinase $\mathrm{K}$ treatment $(P=0 \cdot 003)$, suggesting that this serum reacted with short lipopeptides in the Triton $\mathrm{X}$ 114 extract. To evaluate the potential acylated $C^{1}$ binding ability of serum 3 , the synthetic lipopeptide $\mathrm{Pam}_{3}$-CYS, which mimics a classical lipoprotein $\mathrm{N}$ - terminus, was used as the antigen in ELISA. Serum 3, but no other serum, reacted with $\mathrm{Pam}_{3}$-CYS $(P=0 \cdot 004)$. Serum 3 binding to $M$. penetrans Triton X-114 antigens was significantly reduced $(-18 \%, P=0.01)$ if it was preincubated with $\mathrm{Pam}_{3}$-CYS prior to ELISA (data not shown).

Other putative post-translational modification sites in the deduced P35 amino acid sequence were predicted. In particular, there is a potential tyrosine-phosphorylation site, $\mathrm{K}^{252}$ VLEKLGY ${ }^{259}$. P35 phosphorylation was evaluated by culturing $M$. penetrans in $\mathrm{H}_{3}{ }^{32} \mathrm{PO}_{4}$-containing SP-4 followed by Triton X-114 fractionation, SDS-PAGE and autoradiography. Although a few $M$. penetrans polypeptides which sequestered in the aqueous phase after Triton X-114 extraction were phosphorylated, neither P35 nor any of the other polypeptides in the detergent phase were phosphorylated (data not shown). In addition, there was the possibility of an intramolecular $\mathrm{C}^{\mathbf{1 4 5}}-\mathrm{C}^{\mathbf{2 8 3}}$ disulphide bond in P35. However, cysteine reduction by DTT and - $\mathrm{SH}$ alkylation with iodoacetamide did not alter the antigenicity of P35 as assessed by ELISA. This finding is consistent with the fact that the electrophoretic mobilities of reduced and non-reduced forms of the $M$. penetrans Triton X-114 antigens were indistinguishable in a polyacrylamide gel (data not shown). 
Table 1. Amino acid sequence of the synthetic peptides and recognition frequencies by human or macaque sera

\begin{tabular}{|c|c|c|c|c|c|c|}
\hline $\begin{array}{l}\text { Peptide } \\
\text { no. }\end{array}$ & Peptide sequence & $\begin{array}{c}\text { Epitope } \\
\text { prediction* }\end{array}$ & $\begin{array}{c}\mathrm{HIV}^{+} / \\
\text {M. penetrans } \\
\text { sera }(n=14) \dagger\end{array}$ & $\begin{array}{c}\mathrm{HIV}^{+} / \\
\text {M. penetrans } \\
\text { sera }(n=26) \dagger \ddagger\end{array}$ & $\begin{array}{c}\quad \mathrm{HIV}^{-/} \\
\text {M. penetrans } \\
\text { serum }(n=1) \mathbb{S}\end{array}$ & $\begin{array}{c}M . \text { penetrans } \\
\text { infected } \\
\text { macaques }(n=3) \|\end{array}$ \\
\hline 1 & $\mathrm{C}^{1}$ SSTSENNGNGN ${ }^{12}$ & + & 2 & $12^{b}$ & + & \\
\hline 2 & $S^{5} E_{N N G N G N G N G G}^{16}$ & + & 4 & 8 & & \\
\hline 7 & $E^{25}$ VTPAIKSEVSL $^{36}$ & & 4 & 8 & & ++ \\
\hline 8 & $\mathrm{~A}^{29} \mathrm{IKSEVSLTGAL}^{40}$ & & 2 & 4 & & + \\
\hline 11 & $\mathrm{~S}^{41} \mathrm{KIYDTKTGTDR} 52$ & & 2 & 8 & + & \\
\hline 12 & $\mathrm{D}^{45} \mathrm{TKTGTDRETTS}^{56}$ & & 4 & 8 & + & \\
\hline 13 & $\mathrm{G}^{49} \mathrm{TDRETTSQMIV}^{60}$ & & 4 & 8 & & \\
\hline 14 & $\mathrm{E}^{53} \mathrm{TTSQMIVKDIK}^{64}$ & & 1 & 2 & & + \\
\hline 16 & $\mathrm{~K}^{61}$ DIKANPENYFT ${ }^{72}$ & + & 1 & 5 & & + \\
\hline 17 & $\mathrm{~A}^{65} \mathrm{NPENYFTNGEA}^{76}$ & + & 0 & 5 & & + \\
\hline 24 & $\mathrm{~T}^{93}$ ESTFTGEAYSV $^{104}$ & & 0 & 3 & & + \\
\hline 25 & $\mathrm{~F}^{97} \mathrm{TGEAYSVWSAK}^{108}$ & & 2 & $17^{c}$ & + & ++ \\
\hline 31 & $\mathrm{~K}^{121} \mathrm{QMDIKSINDLQ}{ }^{132}$ & & 0 & 4 & & + \\
\hline 37 & $\mathrm{C}^{145} \mathrm{DLIPNLKLNNG}^{156}$ & + & 2 & 9 & + & + \\
\hline 38 & $\mathrm{P}^{149}$ NLKLNNGTDYK ${ }^{160}$ & + & 1 & 6 & & + \\
\hline 49 & $\mathrm{P}^{193}$ VSDLNLKIDGL ${ }^{204}$ & & 0 & $7^{b}$ & + & + \\
\hline 50 & $\mathrm{~L}^{197} \mathrm{NLKIDGLKISV}^{208}$ & & 2 & 5 & & + \\
\hline 60 & $\mathrm{P}^{237}$ AAVTLAEADR ${ }^{248}$ & & 0 & $7^{b}$ & + & + \\
\hline 61 & $\mathrm{~T}^{241} \mathrm{LAEADRTNAEK}^{252}$ & & 3 & 6 & & + \\
\hline 63 & $\mathrm{~N}^{249}$ AEKVLEKLGYA ${ }^{260}$ & & 1 & 2 & & + \\
\hline 73 & $\mathrm{~K}^{289} \mathrm{SEKDSTNNNKY^{300 }}$ & + & 4 & $15^{a}$ & + & \\
\hline 74 & $\mathrm{D}^{293} \mathrm{STNNNKYTVTL}{ }^{304}$ & + & 3 & 8 & & \\
\hline 75 & $\mathrm{~N}^{297}$ NKYTVTLKATP ${ }^{308}$ & + & 2 & 9 & & \\
\hline 76 & $\mathrm{~T}^{301}$ VTLKATPNDGY ${ }^{312}$ & + & 2 & 7 & & \\
\hline 77 & $\mathrm{~K}^{305}$ ATPNDGYFWED ${ }^{316}$ & + & 2 & $11^{a}$ & + & \\
\hline 78 & $\mathrm{~N}^{309}$ DGYFWEDGTNG ${ }^{320}$ & + & 3 & 9 & & \\
\hline
\end{tabular}

"Epitopes predicted according to Jameson $\&$ Wolf (1988). The peptides predicted to be the most antigenic are indicated by.+ See also Fig. 3.

† Number of sera with $A_{492}>\mathrm{CO}_{50}$.

$\ddagger$ Significant differences between $\mathrm{HIV}^{+}$and $M$. penetrans ${ }^{-}$versus $M$. penetrans ${ }^{+}$populations are indicated by italic superscript characters : $a, P<0.08 ; b, P<0.05 ; c, P<0.001$.

$\$$ The peptides for which the $A_{492}$ value was higher than the determined $\mathrm{CO}_{50}(0.085)$ are indicated as + .

$\|$ The number of + symbols indicates the number of animal sera, out of 3 , reacting with the peptide.

There are two putative $N$-glycosylation sites, $N^{155} \mathrm{GT}^{157}$ and $N^{176} \mathrm{VT}^{178}$, and one putative $O$-glycosylation site (Hansen et al., 1995), $T^{27}$, in the deduced sequence of P35. We previously demonstrated by periodic acid-Schiff staining after SDS-PAGE of M. penetrans Triton X-114 extracted polypeptides that P35 is not glycosylated, at least within the detection limits of this method (Neyrolles et al., 1998). We also demonstrated that no $M$. penetrans polypeptide contains either glucose or mannose (data not shown) by Western blotting using ConA as a probe.

\section{Nonsequential B-epitopes of the P35}

To obtain a recombinant $\mathrm{P} 35$ we changed the two inframe TGA codons in the $p 35$ gene to TGG to allow efficient expression in E. coli. To facilitate the puri- fication of the recombinant protein $\mathrm{rP} 35 \Delta 0$, the $p 35$ gene was inserted into the vector $\mathrm{pQE} 31$ giving $\mathrm{pQEP} 35 \Delta 0$, which resulted in the addition of an $\mathrm{His}_{6} \mathrm{~N}$-terminal tag. By directed mutagenesis of $\mathrm{pQEP} 35 \Delta 0$, the recombinant product $\mathrm{rP} 35 \Delta 3(21.6 \mathrm{kDa})$ which corresponds to the first 182 amino acids of P35 was also produced (Fig. 7a). Culture extracts were subjected to Ni-affinity chromatography and the fractions analysed by SDS-PAGE. Protein $\mathrm{rP} 35 \Delta 0$ was recovered from the E. coli cytoplasmic fraction with only two minor polypeptides using this one-step purification procedure (Fig. $7 \mathrm{~b}$, lanes 1 and 2). In contrast, using similar conditions of elution from the affinity column, the purity of rP35 33 preparations was always lower (Fig. 7b, lanes 3 and 4).

The antigenicity of both proteins was studied by Western blotting using a panel of sera (Fig. 7c). The rabbit polyclonal serum, used as a positive control, 


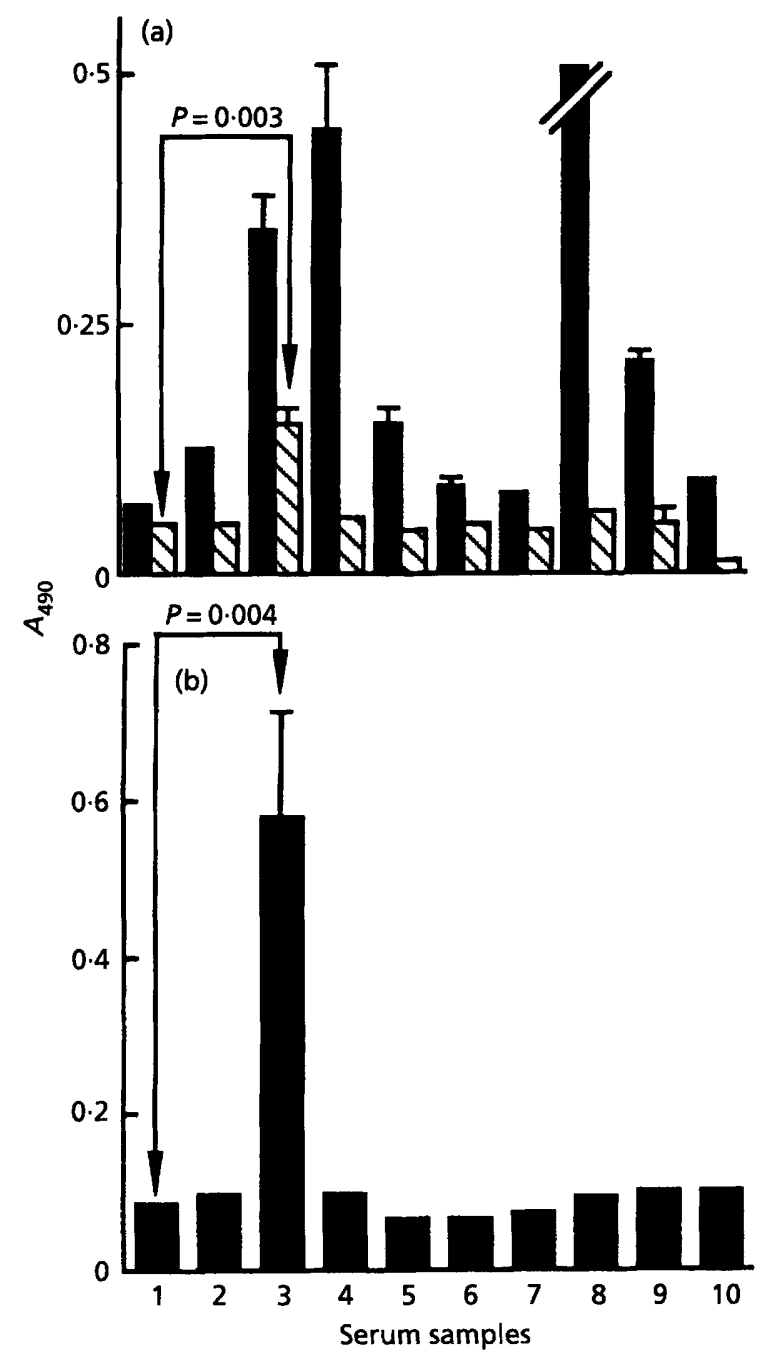

Fig. 6. Involvement of the P35 polypeptide and acylated Nterminal moiety in its antigenicity. (a) Ability of human $M$. penetrans-seronegative (1) vs -seropositive $(2-10)$ sera, used at $1: 100$ dilution, to react with proteinase $\mathrm{K}$-treated $M$. penetrans Triton X-114 extracted antigens, as determined by ELISA. $M$. penetrans Triton X-114 extract digested (hatched) or undigested (black) with proteinase $K$ was used as the antigen. (b) $\mathrm{Pam}_{3}$-CYS lipopeptide used as the antigen.

reacted with both $\mathrm{rP} 35 \Delta 0$ and $\mathrm{rP} 35 \Delta 3$ (Fig. $7 \mathrm{c}$; lane 10), whereas the corresponding pre-immune serum was negative (Fig. 7c; lane 9). Six human sera, selected for their reactivity with the native $\mathrm{P} 35$ from the $M$. penetrans Triton X-114 extract were tested. All reacted with $\mathrm{rP} 35 \Delta 0$ but only one reacted with $\mathrm{rP} 35 \Delta 3$ (Fig. $7 \mathrm{c}$; lane 6).

\section{DISCUSSION}

The P35 sequence contains a typical lipoprotein signal sequence, consistent with previous results showing that P35 is acylated (Ferris et al., 1995). Mycoplasma lipoproteins are thought to be exposed on the cell surface and anchored to the lipid bilayer through their $\mathrm{N}$-terminal lipid moiety (Wieslander et al., 1992). We used a monoclonal anti-P35 antibody to demonstrate that P35 is located on the external surface of the $M$. penetrans plasma membrane. It has been suggested that P35 is involved in M. penetrans cytadherence (Giron et al., 1996). However, our results indicate that P35 is distributed all over the plasma membrane and is not confined to the tip structure, which mediates cytadherence (Lo et al., 1992). This is in constrast with other mycoplasmal adhesins and adhesin-related polypeptides such as P1, P30, P90 and HMW3 in M. pneumoniae or $\mathrm{MgPa}$ in $M$. genitalium, which have been shown to be clustered at the cell tip (for a review see Krause, 1996). However, the P50 adhesin of M. hominis, a mycoplasma that lacks the tip structure, was shown to be distributed all over the cell surface (Henrich et al., 1993). Therefore, our findings do not exclude that P35 plays a role in $M$. penetrans cytadherence. The abundance of P35 and its exposure at the cell surface are in agreement with this lipoprotein being targeted by the humoral arm of the host immune system (Grau et al., 1995; Wang et al., 1992). To identify the major linear antigenic regions of P35, we used a set of synthetic peptides covering the entire P35 amino acid sequence. This ELISA-based technique is now widely used to define sequential epitopes in a protein and its advantages and disadvantages have been reviewed by Geysen et al. (1987). A similar approach has previously been used for $\mathrm{T}$ epitope mapping in various bacterial antigens including the Mycobacterium bovis P38 (Pollock et al., 1995), and for B-epitope mapping of the Pg-II fimbria from Porphyromonas gingivalis (Ogawa et al., 1995) and of the MB antigen from U. urealyticum (Zheng et al., 1996). This strategy is particularly suitable for mapping sequential epitopes of three to eight amino acid residues (Arnon \& Van Regenmortel, 1992; Geysen et al., 1987). To map epitopes as small as four amino acid residues, we used dodecapeptides, each one overlapping the previous by eight amino acid residues. It is unlikely that the changes in signal in our epitope characterization experiments were due to different amounts of the peptides bound to the microtitre wells. The results obtained with immunized animal sera (rabbit and macaque) are partly in accordance with the predicted antigenic profile of P35 (Fig. 3); peptides predicted to be highly antigenic were well recognized by hyperimmune rabbit sera (e.g. $\mathrm{T}^{17}{ }^{1}$ GNTQQT ${ }^{24}$ with a mean AI of 1.081). However, other amino acid sequences, such as $\mathrm{T}^{37}$ GALSKIY ${ }^{44}$ and $\mathrm{A}^{321}$ KEEISFVATFS $^{332}$, which were predicted to be poorly antigenic (mean AI of -0.206 and -0.012 , respectively) were also well recognized by these sera. Similarly, peptide $14\left(\mathrm{E}^{53} \mathrm{TTS}\right.$ QLIVKDIK $\left.{ }^{64}\right)$, which was predicted to be weakly antigenic (mean AI of 0.250), gave the strongest reaction with hyperimmune serum from rabbit 2. Peptides encompassing amino acid residues $\mathrm{N}^{154} \mathrm{NGT}^{157}$ were predicted to be highly antigenic (AI 1.700), but were not recognized by hyperimmune sera. Finally, the immunized macaque 9063 serum reacted only, but very significantly, with peptides $\mathrm{A}^{29}{ }^{2} \mathrm{KSEVSLTGAL}{ }^{40}$ (predicted to be poorly antigenic) 
(a)

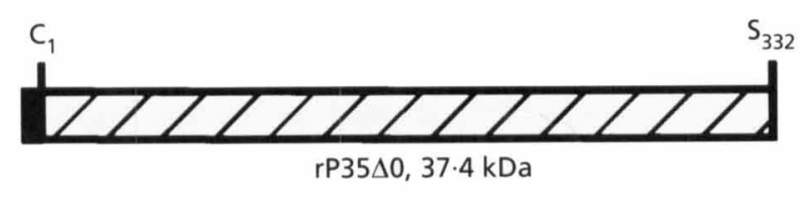

(b)
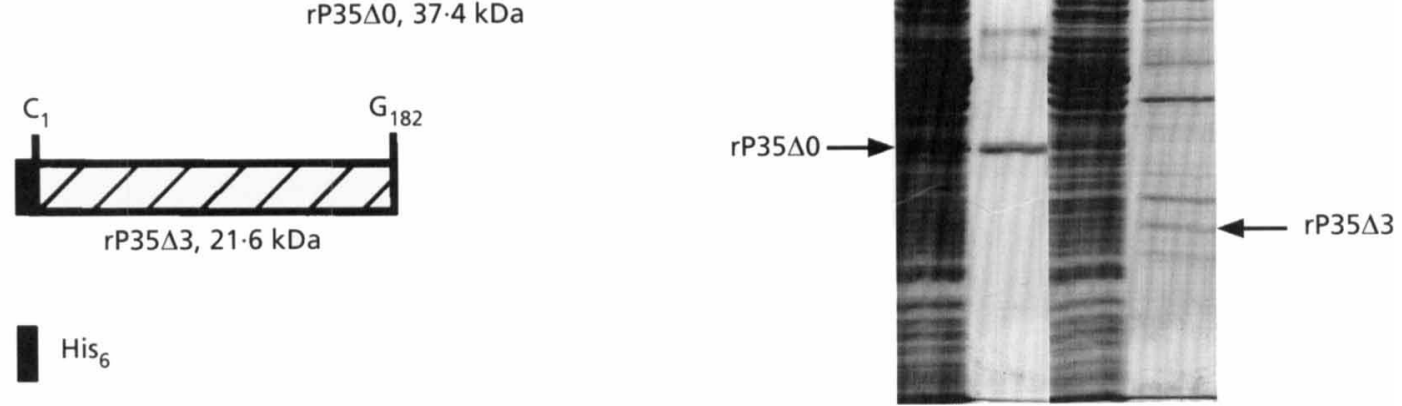

(c)

$\mathrm{His}_{6}$
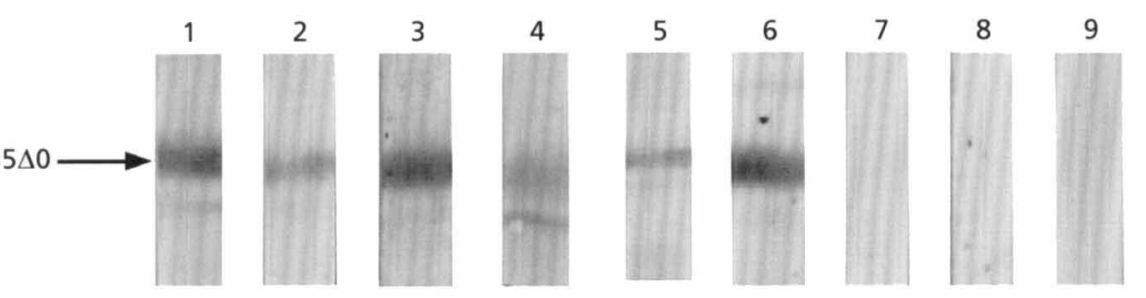

10
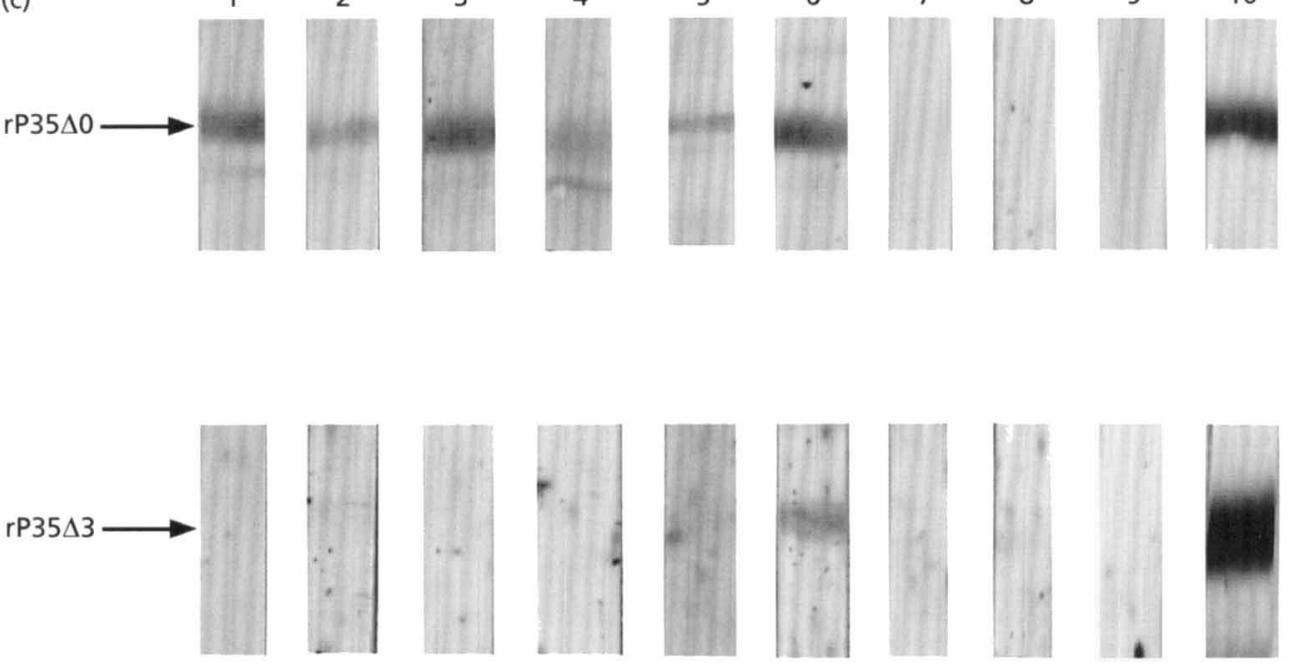

Fig. 7. Purification and antigenicity of the two recombinant P35 proteins. (a) Schematic representation of the recombinant proteins $\mathrm{rP} 35 \Delta 0$ and $\mathrm{rP3} \Delta \Delta 3$ obtained by directed mutagenesis. (b) SDS-PAGE analysis of fractions containing rP35 $\Delta 0$ and $r P 35 \Delta 3$. rP35 $\Delta 0$ and $r P 35 \Delta 3$ production was induced from $E$. coli transformants containing the plasmids PQEP $35 \Delta 0$ and PQEP35 $\Delta 3$, respectively. The polypeptide content of cytoplasmic fractions from these transformants was analysed ( $E$. coli with pQEP35 $\Delta 0$, lane $1 ; E$. coli with PQEP35 $\Delta 3$, lane 3 ). Fractions eluted from the $\mathrm{Ni}$ affinity chromatography containing rP35 $\Delta 0$ and rP35 $\Delta 3$ are shown in lanes 2 and 4 , respectively. (c) Evaluation of antigenicity of rP35 $\Delta 0$ and $r P 35 \Delta 3$ by Western blotting. The pre-immune (lane 9) and hyperimmune (lanes 10) rabbit 2 sera were tested at a 1:500 dilution. Sera from $M$. penetrans-seropositive (lanes 1-6) and -seronegative (lanes 7, 8) humans were tested at a 1:50 dilution. The development of the enzymic reaction was stopped simultanously for all Western blot strips tested with human sera.

and $\mathrm{Y}^{281} \mathrm{NCKFEAVKSEK}{ }^{292}$ (mean AI of $-0 \cdot 237$ and $0 \cdot 512$, respectively).

The reaction profiles for infected macaques and patients differ significantly from those for immunized animals. This is most likely due to the combination of at least two factors: the P35 polypeptide used to inoculate rabbits was partially denatured and the repertoire of B epitopes recognized in different animal species is known to vary (Berzofsky, 1985).

The profiles obtained with infected macaques and patients shared several common features. In particular, peptide 25 was recognized by two infected macaques and by about $66 \%$ of the $M$. penetrans seropositive patients $(P<0 \cdot 001)$. The HIV serological status of the human donors clearly interfered with this epitopemapping analysis by generating a high level of background. This difficulty was probably due to the polyclonal B cell activation and IgG hypersecretion which occur during HIV infection (Lane et al., 1983). However, it was not possible to limit our study to HIV-seronegative patients due to the low incidence of $M$. penetrans-seropositivity in this population $(0.3-1 \cdot 3 \%$; Brenner et al., 1996). The heterogeneity of the antibody response observed in HIV-infected patients was more likely due to a combination of factors which include the diversity of their MHC genes and of their Ig gene repertoire, and the effects of HIV infection on the repertoire of immune cells. MHC genes act indirectly, by influencing the level and specificity of helper $\mathrm{T}$ 
lymphocytes, which are required for activation of B cells to make antibodies against protein antigens. Examples of the MHC control of the specificity of antibody production include responses to the hepatitis B surface antigen (Milich et al., 1984) and to peptides of myelin basic protein (Fritz et al., 1985). The perturbation of the repertoire of $\mathrm{T}$ helper cells is one of the landmarks of HIV infection and has indirect effects on antibody production (Gorochov et al., 1998).

In spite of this heterogeneity in the antibody response, peptides $1,2,37,38$ and 73-78, which were predicted to contain the most antigenic amino acid residues (Fig. 3), were significantly $(\geqslant 25 \%)$ recognized by sera from HIV- and $M$. penetrans-seropositive patients. Two peptides reacted with most $M$. penetrans-seropositive sera, peptides $1(46 \cdot 1 \%)$ and $25(65.4 \%)$, but only with $14 \%$ of $M$. penetrans-seronegative sera $(P<0.05$ and 0.001 , respectively). The recombinant form of $\mathrm{P} 35$, rP35 $\Delta 0$, was recognized by all the sera from $M$. penetrans-seropositive patients tested in this study. Only one in six of these human sera reacted with $\mathrm{rP} 35 \Delta 3$, indicating that either the region corresponding to the P35 C-terminal moiety contains major linear epitopes or that conformational determinants involving this region are recognized by patient sera. These two possibilities are not exclusive and were supported by our data from ELISA with the set of synthetic peptides. Indeed, among the human sera which reacted with P35 on Western blots, some did not show any significant reactivity with the set of P35-derived peptides, whereas others which were found to contain antibodies to linear B-epitopes were reactive with numerous peptides from the P35 Cterminus. In addition, the rabbit PAb 2 , which reacted with rP35 $\Delta 3$, recognized linear B-epitopes located at the $\mathrm{N}$-terminus of P35.

The linear epitopes defined using the panel of 81 overlapping peptides only represent antigenic regions with no post-translational modifications. Therefore, we also investigated the possibility that other features of $M$. penetrans P35 could contribute to its antigenicity, in particular its N-terminal lipid moiety. Many lipid moieties of bacterial lipoproteins are strongly immunogenic, and are potent activators of $B$ cells and macrophages. These properties were documented by the use of structural analogues of the N-terminal lipopeptide domain of Braun's lipoprotein from $E$. coli (Hauschildt et al., 1990; Melchers et al., 1975), and with lipidated or non-lipidated forms of the B. burgdorferi OspA (Erdile et al., 1993). It was also shown that the $\mathrm{N}$-terminal lipid moiety of the P47 major membrane antigen from $T$. pallidum is not an antigenic structure (Weigel et al., 1992). Similarly, Shouls et al. (1991) demonstrated that the lipid moiety of the TmpA and TmpC surface lipoproteins from $T$. pallidum strongly enhanced the antibody response in animals, acting as both carrier and adjuvant, but that all the anti-TmpA and -TmpC antibodies were exclusively directed against the polypeptide parts of these lipoproteins. We showed that the protein moiety of the $M$. penetrans Triton X-114 antigens carried the majority of the B-epitopes recog- nized by human sera. Indeed, proteinase $\mathrm{K}$ treatment of these antigens abolished their reactivity. However, for one of 9 sera (serum 3, Fig. 6a), the proteinase $\mathrm{K}$ treatment did not entirely eliminate the immune recognition of $M$. penetrans Triton X-114 antigens. This serum bound a synthetic lipopeptide (Fig. 6b) and this binding was, at least in part, competitive with binding to $M$. penetrans Triton X-114 antigens. To our knowledge, this is the first data indicating that, at least in a few cases, human sera can react with the $\mathrm{N}$-terminal lipid moiety of bacterial lipoproteins.

We have evaluated whether other post-translational modifications of P35 were involved in its antigenicity. The putative intramolecular $\mathrm{C}^{145}-\mathrm{C}^{283}$ disulphide bond did not contribute to P35 antigenicity, whereas such a disulphide bond was found to be essential for the antigenicity of the $\mathrm{P} 29$ polypeptide from $M$. fermentans (Theiss et al., 1996). Although it was suggested by Andreev et al. (1995) that P35 might be phosphorylated, our data indicated that it was not the case. Finally, our preliminary data did not suggest that P35 is glycosylated, but this modification cannot yet be excluded.

We are currently investigating the possibiliy of using a cocktail of P35-derived synthetic peptides (such as both peptides 1 and 25) or adding this cocktail to Triton X114 antigens, to improve the $M$. penetrans serological assay. In addition, we are addressing whether $\mathrm{rP} 35 \Delta 0$ can be used as the antigen, instead of the crude Triton X114 extract, in a new version of the $M$. penetransspecific ELISA.

\section{AKNOWLEDGMENTS}

We thank I. Chambaud, L. Dieu and S. Dupré for excellent technical assistance. We also thank Emmanuelle Perret and Christine Schmitt for their technical assistance in electron microscopy, and O. Grau and S. Chamaret for providing some of the human sera used in this study. This work was supported by the Agence Nationale de Recherche contre le SIDA (ANRS) and the Institut Pasteur. O.N. was a recipient of a fellowship from the Pasteur-Weizman Foundation, and J.-P.E. from the French Ministère des Affaires Etrangères.

\section{REFERENCES}

Adam, T., Arpin, M., Prevost, M. C., Gounon, P. \& Sansonetti, P. J. (1995). Cytoskeletal rearrangements and the functional role of T-plastin during entry of Shigella flexneri into HeLa cells. $J$ Cell Biol 129, 367-381.

Andreev, J., Borovsky, Z., Rosenshine, I. \& Rottem, S. (1995). Invasion of HeLa cells by Mycoplasma penetrans and the induction of tyrosine phosphorylation of a $145 \mathrm{kDa}$ host cell protein. FEMS Microbiol Lett 132, 189-194.

Antoni, G., dal Maso, G., Berti, B., Soldatini, C. \& Cocola, F. (1996). Detection of antigenic determinants in the Treponema pallidum membrane protein TmpA using overlapping synthetic peptides. J Immunol Methods 189, 137-140.

Arnon, R. \& Van Regenmortel, M. H. (1992). Structural basis of antigenic specificity and design of new vaccines. FASEB $J \mathbf{6}$, $3265-3274$. 
Berzofsky, J. A. (1985). Intrinsic and extrinsic factors in protein antigenic structure. Science 229, 932-940.

Blanchard, A. (1997). Mycoplasmas and HIV infection, a possible interaction through immune activation. Wien Klin Wochenschr 109, 590-593.

Blanchard, A. \& Montagnier, L. (1994). AIDS-associated mycoplasmas. Annu Rev Microbiol 48, 687-712.

Blanchard, A., Montagnier, L. \& Gougeon, M. L. (1997). Influence of microbial infections on the progression of HIV disease. Trends Microbiol 5, 326-331.

Brenner, C., Neyrolles, O. \& Blanchard, A. (1996). Mycoplasmas and HIV infection: from epidemiology to their interaction with immune cells. Front Biosci 1, 42-54.

Chou, P. Y. \& Fasman, G. D. (1978). Empirical predictions of protein conformation. Annu Rev Biochem 47, 251-276.

Erdile, L. F., Brandt, M. A., Warakomski, D. J., Westrack, G. J., Sadziene, A., Barbour, A. G. \& Mays, J. P. (1993). Role of attached lipid in immunogenicity of Borrelia burgdorferi OspA. Infect Immun 61, 81-90.

Ferris, S., Watson, H. L., Neyrolles, O., Montagnier, L. \& Blanchard, A. (1995). Characterization of a major Mycoplasma penetrans lipoprotein and of its gene. FEMS Microbiol Lett 130, 313-319.

Fritz, R. B., Skeen, M. J., Chou, C. H., Garcia, M. \& Egorov, I. K. (1985). Major histocompatibility complex-linked control of the murine immune response to myelin basic protein. J Immunol 134, 2328-2332.

Garbe, T., Harris, D., Vordermeier, M., Lathigra, R., Ivanyi, J. \& Young, D. (1993). Expression of the Mycobacterium tuberculosis 19 kilodalton antigen in Mycobacterium smegmatis: immunological analysis and evidence of glycosylation. Infect Immun 61, 260-267.

Garnier, J., Osguthorpe, D. J. \& Robson, B. (1978). Analysis of the accuracy and implications of simple methods for predicting the secondary structure of globular proteins. J Mol Biol 120, 97-120.

Geysen, H. M., Rodda, S. J., Mason, T. J., Tribbick, G. \& Schoofs, P. G. (1987). Strategies for epitope analysis using peptide synthesis. $J$ Immunol Methods 102, 259-274.

Giron, J. A., Lange, M. \& Baseman, J. B. (1996). Adherence, fibronectin binding, and induction of cytoskeleton reorganization in cultured human cells by Mycoplasma penetrans. Infect Immun 64, 3419-3424.

Gorochov, G., Neumann, A. U., Kereveur, A. \& 7 other authors (1998). Perturbation of CD4+ and CD8 + T-cell repertoires during progression to AIDS and regulation of the CD4+ repertoire during antiviral therapy. Nat Med 4, 215-221.

Grau, O., Slizewicz, B., Tuppin, P. \& 10 other authors (1995). Association of Mycoplasma penetrans with human immunodeficiency virus infection. $J$ Infect Dis 172, 672-681.

Grau, O., Tuppin, P., Slizewicz, B., Launay, V., Goujard, C., Bahraoui, E., Delfraissy, J. F. \& Montagnier, L. (1998). A longitudinal study of seroreactivity against Mycoplasma penetrans in HIV-infected homosexual men: association with disease progression. AIDS Res Human Retrovir 14, 661-667.

Hansen, J. E., Lund, O., Engelbrecht, J., Bohr, H., Nielsen, J. O. \& Hansen, J. E. (1995). Prediction of O-glycosylation of mammalian proteins: specificity patterns of UDP-GalNAc:polypeptide $N$ acetylgalactosaminyltransferase. Biochem $J$ 308, 801-813.

Hauschildt, S., Hoffmann, P., Beuscher, H. U., Dufhues, G., Heinrich, P., Wiesmuller, K. H., Jung, G. \& Bessler, W. G. (1990). Activation of bone marrow-derived mouse macrophages by bacterial lipopeptide: cytokine production, phagocytosis and Ia expression. Eur J Immunol 20, 63-68.

Henrich, B., Feldmann, R.-C. \& Hadding, U. (1993). Cytoadhesins of Mycoplasma hominis. Infect Immun 61, 2945-2951.

Herrmann, J. L., O'Gaora, P., Gallagher, A., Thole, J. E. \& Young, D. B. (1996). Bacterial glycoproteins : a link between glycosylation and proteolytic cleavage of a $19 \mathrm{kDa}$ antigen from Mycobacterium tuberculosis. EMBO J 15, 3547-3554.

Jameson, B. A. \& Wolf, H. (1988). The antigenic index: a novel algorithm for predicting antigenic determinants. Comput Appl Biosci 4, 181-186.

Krause, D. C. (1996). Mycoplasma pneumoniae cytadherence: unravelling the tie that binds. Mol Microbiol 20, 247-253.

Laemmli, U. K. (1970). Cleavage of structural proteins during the assembly of the head of bacteriophage T4. Nature 227, 680-685.

Lane, H. C., Masur, H., Edgar, L. C., Whalen, G., Rook, A. H. \& Fauci, A. S. (1983). Abnormalities of B-cell activation and immunoregulation in patients with the acquired immunodeficiency syndrome. $N$ Engl J Med 309, 453-458.

Le Gall, S., Prevost, M. C., Heard, J. M. \& Schwartz, O. (1997). Human immunodeficiency virus type I Nef independently affects virion incorporation of major histocompatibility complex class 1 molecules and virus infectivity. Virology 229, 295-301.

Lemaitre, M., Henin, Y., Destouesse, F., Ferrieux, C., Montagnier, L. \& Blanchard, A. (1992). Role of mycoplasma infection in the cytopathic effect induced by human immunodeficiency virus type 1 in infected cell lines. Infect Immun 60, 742-748.

Lo, S.-C., Hayes, M. M., Wang, R. Y., Pierce, P. F., Kotani, H. \& Shih, J. W. (1991a). Newly discovered mycoplasma isolated from patients infected with HIV. Lancet 338, 1415-1418.

Lo, S.-C., Tsai, S., Benish, J. R., S!nih, J. W., Wear, D. J. \& Wong, D. M. (1991b). Enhancement of HIV-1 cytocidal effects in CD4+ lymphocytes by the AIDS-associated mycoplasma. Science 251, 1074-1076.

Lo, S.-C., Hayes, M. M., Tully, J. G., Wang, R. Y., Kotani, H., Pierce, P. F., Rose, D. L. \& Shih, J. W. (1992). Mycoplasma penetrans sp. nov. from the urogenital tract of patients with AIDS. Int J Syst Bacteriol 42, 357-364.

Ma, J., Gingrich-Baker, C., Franchi, P. M., Bulger, P. \& Coughlin, R. T. (1995). Molecular analysis of neutralizing epitopes on outer surface proteins A and B of Borrelia burgdorferi. Infect Immun 63, 2221-2227.

Matsushita, K., Nisizawa, T., Nagaoka, S., Kawagoe, M. \& Koga, T. (1994). Identification of antigenic epitopes in a surface protein antigen of Streptococcus mutans in humans. Infect Immun 62, $4034-4042$.

Melchers, F., Braun, V. \& Galanos, C. (1975). The lipoprotein of the outer membrane of Escherichia coli: a B-lymphocyte mitogen. $J$ Exp Med 142, 473-482.

Milich, D. R., Leroux-Roels, G. G., Louie, R. E. \& Chisari, F. V. (1984). Genetic regulation of the immune response to hepatitis $B$ surface antigen (HBsAg). IV. Distinct $\mathrm{H}$-2-linked Ir genes control antibody responses to different $\mathrm{HBsAg}$ determinants on the same molecule and map to the I-A and I-C subregions. J Exp Med 159, 41-56.

Neyrolles, O., Brenner, C., Prevost, M.-C., Fontaine, T., Montagnier, L. \& Blanchard, A. (1998). Identification of two glycosylated components of Mycoplasma penetrans: a surfaceexposed polysaccharide and a glycolipid fraction. Microbiology 144, 1247-1255.

Ogawa, T., Yasuda, K., Yamada, K., Mori, H., Ochiai, K. \& Hasegawa, M. (1995). Immunochemical characterisation and 
epitope mapping of a novel fimbrial protein (Pg-II fimbria) of Porphyromonas gingivalis. FEMS Immunol Med Microbiol 11, 247-255.

Pollock, J. M., Douglas, A. J., Mackie, D. P. \& Neill, S. D. (1995). Peptide mapping of bovine T-cell epitopes for the $38 \mathrm{kDa}$ tuberculosis antigen. Scand J Immunol 41, 85-93.

Sasaki, Y., Blanchard, A., Watson, H. L., Garcia, S., Dulioust, A., Montagnier, L. \& Gougeon, M. L. (1995). In vitro influence of Mycoplasma penetrans on activation of peripheral T lymphocytes from healthy donors or human immunodeficiency virus-infected individuals. Infect Immun 63, 4277-4283.

Schouls, L. M., van der Heide, H. G. \& van Embden, J. D. (1991). Characterization of the 35 kilodalton Treponema pallidum subsp. pallidum recombinant lipoprotein TmpC and antibody response to lipidated and nonlipidated T. pallidum antigens. Infect Immun 59, 3536-3546.

Theiss, P., Karpas, A. \& Wise, K. S. (1996). Antigenic topology of the P29 surface lipoprotein of Mycoplasma fermentans: differential display of epitopes results in high-frequency phase variation. Infect Immun 64, 1800-1809.

Tully, J. G., Whitcomb, R. F., Clark, H. F. \& Williamson, D. L. (1977). Pathogenic mycoplasmas: cultivation and vertebrate pathogenicity of a new spiroplasma. Science 195, 892-894.
Wang, R. Y., Shih, J. W., Grandinetti, T., Pierce, P. F., Hayes, M. M., Wear, D. J., Alter, H. J. \& Lo, S.-C. (1992). High frequency of antibodies to Mycoplasma penetrans in HIV-infected patients. Lancet 340, 1312-1316.

Wang, R. Y., Shih, J. W., Weiss, S. H. \& 8 other authors (1993). Mycoplasma penetrans infection in male homosexuals with AIDS: high seroprevalence and association with Kaposi's sarcoma. Clin Infect Dis 17, 724-729.

Weigel, L. M., Brandt, M. E. \& Norgard, M. V. (1992). Analysis of the $\mathrm{N}$-terminal region of the 47 kilodalton integral membrane lipoprotein of Treponema pallidum. Infect Immun 60, 1568-1576.

Wieslander, A., Boyer, M. J. \& Wroblewski, H. (1992). Membrane protein structure. In Mycoplasmas: Molecular Biology and Pathogenesis. Edited by J. Maniloff, R. N. McElhaney, L. R. Finch \& J. B. Baseman. Washington, DC: American Society for Microbiology.

Zheng, X., Lau, K., Frazier, M., Cassell, G. H. \& Watson, H. L. (1996). Epitope mapping of the variable repetitive region with the $\mathrm{MB}$ antigen of Ureaplasma urealyticum. Clin Diagn Lab Immunol 3, 774-778.

Received 27 May 1998; revised 28 September 1998; accepted 14 October 1998. 